\title{
Speech acts performed by echo questions in English conversational discourse
}

\author{
N. S. Strelchenko
}

Kyiv National Linguistic University

Corresponding author. E-mail: eglantine@ukr.net

Paper received 30.03.19; Accepted for publication 11.04.19.

\author{
https://doi.org/10.31174/SEND-Ph2019-195VII59-17
}

Abstract. The article examines illocutionary characteristics of echo questions in English conversational discourse, identifying the types of speech acts performed and specifying their felicity conditions. Drawing on data from British and American films and prose, the research revealed that echo questions may be realized as direct speech acts (quesitives) as well as combine several illocutions functioning as indirect directives, expressives, metacommunicatives, constatives, and commissives.

Keywords: echo question, speech act, quesitive, directive, expressive, metacommunicative, constative, commissive, conversational discourse.

Introduction. Echo questions, common in conversational discourse [0, p. 99], have been defined on the basis of their functional characteristics (to ask a question, express emotions, check one's understanding of the interlocutor's message, or make further inquiries) as well as structural and semantic relation with the preceding utterance [0] Their differentiation into certain types of speech acts [0] is made possible by establishing their communicative intention ("orientation of a sentence towards achieving a certain linguistic communicative aim" [0, p. 433]), which makes the present study topical.

This paper aims to identify the types of speech acts performed by echo questions as well as specify their felicity conditions.

Material and methods. Echo questions, selected by continuous sampling from prose works of British and American authors of the 20th and 21st centuries as well as English feature films have been studied by means of descriptive and pragmatic methods.

Literature review. Types and characteristics of speech acts have been explored by J. Austin [0], J. Searle [0], K. Bach and R. Harnish [0], G. Leech [0, p. 207-226], D. Wunderlich [0], and G.G. Pocheptsov [0, p. 435-444]. Generalizing the results of speech act classifications, I.S. Shevchenko has offered a typology of speech acts relevant for a diachronic study of the English interrogative sentence based on J. Searle's and G.G. Pocheptsov's ideas, thus distinguishing quesitives ("inquiring about new important information to bridge the information gap"), directives (injunctives - inducements-orders and requestives - inducements-requests), expressives (expressing evaluation and emotions), metacommunicatives (speech acts which precede establishing speech contact, speech acts prolonging contact, and speech acts terminating speech contact), constatives (which ensure "communicating new important information"), and commissives (menasives - warnings, threats; promisives - promises, offers) [0, p. 50].

Results and discussion. The illocutionary force of a quesitive is realized when echo questions are used to request elaboration (clarification / repetition) on the elements of the interlocutor's utterance, check an inference / assumption, and ask for confirmation or commitment [0, p. 181-182].

Assuming that a question (quesitive) requires that the speaker should not know its answer [0, p. 362-363], we may formulate felicity conditions of echo questions func- tioning as quesitives in the following manner (based on felicity conditions of a directive speech act [0, p. 80]):

perlocutionary condition - the speaker (B) is going to obtain the answer;

preparatory conditions - the addressee (A) is in a position to give the answer, the speaker $(\mathrm{B})$ has the right to ask and is not certain about obtaining the answer in the normal course of events; requesting elaboration: B does not know the (details of) the answer; requesting clarification: B does not know the answer (due to a misunderstanding); requesting repetition: $\mathrm{B}$ does not know the answer (due to various problems pertaining to perception of A's utterance); checking an inference / assumption: the truth thereof should necessarily be confirmed by A; asking for confirmation: $\mathrm{B}$ is uncertain / doubtful about A's utterance; asking for commitment: B wants A to behave in a certain way / perform a certain action in the future; B's asking for commitment is necessary for A to perform the action in question [0];

propositional content condition - a future action of the addressee (providing the required answer);

sincerity condition - the speaker (B) really wants the addressee (A) to provide the answer;

essential conditions - the speaker's attempts to obtain the answer from the addressee;

individualized conditions specify the element of A's utterance which requires elaboration / clarification / repetition / confirmation.

The interrelation of formal and functional features of an utterance is characterized by a certain flexibility, which allows a quesitive to acquire additional illocutions of other speech acts [0, p. 444-446]. A directive may take the form of an injunctive, which pertains to the interlocutor's actions / behaviour / attitude (examples in (1)) or the unfolding of the common communicative activity (the necessity of discussing a certain subject at a certain time, the truthfulness of the interlocutor's message and his / her sincerity, inducement to provide information) (examples in (2)). It is noteworthy that modal meanings of necessity, obligation, and possibility may be actualized in both (1) and (2):

(1) Why don't you come and see? [0]; Why don't you leave her alone? [0]; Is it necessary to trouble Her Ladyship any further, sir? [0]; Must you interfere? Does it really matter if he marries the girl? [0, p. 1046]; But does one have to be so proud? [0]; Do you have to take them all? [0]; May I see this letter? [0]; 
(2) Can't this wait? [0]; Do we have to talk about this? [0]; Can't you stop talking about murder? [0]; Can you lie to me just once? [0]; Can you tell me where I might find him this evening, Monsieur? [0]; Would you mind explaining, Doctor? [0].

A requestive is realized in the form of a recommendation / advice (examples (3)-(5)) or request (6). In comparison with injunctives, these utterances are less categorical due to the use of modal verbs, the pragmatic marker please [0, p. 189], discourse markers and hedges: well $[0$, p. 59] expressing the meaning of disagreement / doubt [0, p. 851-852] and $o h$ [0, p. 321; 0, p. 267]) as well as transposition of the grammatical category of person of the pronoun [0, p. 79-85]: the use of the first person plural instead of the second.

(3) Then may I recommend that you return there and be on hand in case I should want you? [0, p. 819];

(4) Princess Shaista: Perhaps I'll find my husband here, in England.

Miss Bulstrode: Yes, well, we mustn't run before we can walk, must we? [0];

(5) You will be careful, won't you? [0];

(6) Bobby: Come inside.

Moira: Oh, no, please, before we go inside, isn't there somewhere we could go-a cafe that's safe? [0].

In communicative situation (7), evaluation (an expressive) is combined with an implicit directive ("a situationbound directive with contextual illocutionary indicators" $[0$, p. 75$]$ ), while in (8) requesting confirmation (a quesitive) is intertwined with the expression of surprise:

(7) Morse: Have a look at my glass first.

Lewis: It's a bit early for a second, isn't it, sir? [0].

(8) Bobby Jones and Reverend Jones are having breakfast. Bobby: Well, I'm damned.

Reverend Jones: Really, Bobby!

Bobby: Oh, sorry, Dad, I forgot you were there. But somebody's offered me a thousand a year.

Reverend Jones: What did you say? A thousand? A thousand pounds?

Bobby: Hold and wonder [0].

When echo questions are used as metacommunicatives, their function is maintaining speech contact by expressing empathy and interest. Demonstrating attention to the interlocutor's message may be accompanied by urging him / her to continue speaking and provide more information [0, p. 400].

A constative has the illocutionary force of a statement [0, p. 437], whereas indirect constatives, according to I.S. Shevchenko, realize at least two illocutionary forces: informing and inquiring [0, p. 117]:

(9) Miss Bunner: I saw him with an oil can in the garden.

Miss Marple leaning forward: Really?

Miss Bunner: And the other door to the drawing room has been oiled. And I heard him having an argument with Julia the other day.

Miss Marple: But that's human nature, isn't it? Arguments between brothers and sisters [0].

Miss Marple's echo questions present a combination of two illocutions: Really? requests elaboration and demonstrates interest in the facts communicated by Miss Bunner and her version of events, while Miss Marple's second echo question simultaneously expresses her own view on the subject under discussion.

Rhetorical questions also belong to indirect constatives [0, p. 76-77]. Unlike quesitives, they do not inquire about new information [0, p. 77] because the answer is known to both communicators (can be provided by either of them) and is part of the common ground. The aim of a rhetorical question is drawing the interlocutor's attention to a particular element of the common ground, which constitutes the answer to a rhetorical question, rather than increasing the amount of the communicators' common knowledge [0, p. 131]. In the following situation, a negative answer to Father Brown's rhetorical questions is obvious to his interlocutors and indicates the seriousness of the condition which he is trying to simulate.

(10) Dr. Henshaw: Kleptomania?

Father Brown: Frequently. Mr Hammond's apple tree is a particular casualty.

Dr. Henshaw: Gambling?

Father Brown: I like an occasional flutter.

Nurse Farrow: Occasional?

Father Brown: Every day.

Dr. Henshaw: Compulsive eating?

Father Brown: Oh, who can resist second helpings? Or third? Or fourth? [0].

Obviousness of the answers [0, p. 436] to rhetorical questions on the basis of common knowledge and beliefs [0, p. 164] allows using echo questions in the function of implicit disagreement ("a reactive speech act expressing a speaker's opinion which is different from his / her interlocutor's stance, has the form of an informative or evaluative utterance and is characterized by different emotional colourings (e.g., disapproval, criticism)" [0, p. 3]). For instance, in situation (11), Miss Blacklock's echo questions express doubt about the version of the attempted murder suggested by the police inspector, pointing out its absurdity, and represent a disagreement-constative, which is realized by means of positive evaluation of the neighbours, who are incapable of committing such a crime.

(11) Inspector Craddock: When Scherz came in this door and did his party piece, anybody could've slipped out through the other door, stood behind him and fired the shots at you, Miss Blacklock.

Miss Blacklock: Oh! Are you suggesting that one of my neighbours, one of my nice, commonplace neighbours, slipped through that door and tried to murder me? Oh! Who is your main suspect, Inspector? The vicar's wife? [0].

An implicit disagreement-directive combines criticism of the interlocutor's viewpoint, namely speaking ill of the deceased during the funeral, and inducement to stop discussing the subject:

(12) Dr Crawford: Well, your son was hardly the most respectful of people. John Tatton: How dare you? You seen this? Hm? Dr Crawford: What is it? [0].

An indirect commissive functions as a promisive / asking for instructions in the case of behavioural cooperation and coordination of a common activity (Is there anything I can do? [0]; Any instructions, sir? [0, p. 120]), whereas in conflict situations it may act as a menasive combined with disagreement (an expressive):

(13) "Keep on talking," said Holmes. "It's fine." "Oh! it's fine, is it?" growled the savage. "It won't be so damn 
fine if I have to trim you up a bit. I've handled your kind before now, and they didn't look fine when I was through with them. Look at that, Masser Holmes!" He swung a huge knotted lump of a fist under my friend's nose [0, p. 1059].

A felicitous performance of an indirect commissive / asking for instructions presupposes fulfilling a number of conditions:

perlocutionary condition - the speaker (B) is going to perform an action and requires A's permission / agreement;

preparatory conditions - the speaker (B) is able and willing to perform the action; the speaker (B) cannot perform the action without obtaining permission; the speaker (B) is uncertain about the necessity / appropriateness of performing the action; performance of the future action does not contradict A's interests according to the context of communication;

propositional content condition - a future action by the speaker (B);

sincerity condition - the speaker (B) wants the addressee (A) to agree that the speaker should perform a future action / specify what exactly must be done;

essential conditions - the speaker's attempts to gain the addressee's consent to performance of the action;

individualized conditions specify the characteristics of the action which the speaker wants to perform.

According to G.G. Pocheptsov, a sentence may function as a promisive if the action / event in question depends on the speaker [0, p. 438]. An indirect commissiverefusal $[0, \mathrm{p} .5]$ is characterized by the speaker's unwillingness to perform a certain action (including a verbal one), interlocutors' conflicting goals, the speaker's doubt about the addressee's right to demand performance of a certain (communicative) action by issuing commands / offering suggestions or asking for certain information.

(14) Iggy: Listen, Dan, anything else, I play it your way, right? Just one condition.

\section{Dan: Who says you make conditions?}

Iggy: Just one [0].

In situation (14), a conversation between two bank robbers, Dan's echo question denies Iggy the right to influence their common future actions. In the following situation, echo questions pertain to verbal behaviour:

\section{(15) Patti Randall: Shh!}

Ingrid Randall: What do you mean "shh"? What's going on here?

Zeke Kelso: Now quiet please. to another agent using a transmitter: Report to me when you reach the area.

Ingrid Randall: How dare you tell me to be quiet? to Patti: What's this man doing in my room? [0].

Having returned from work, Ingrid enters her bedroom, sees a stranger (an FBI agent Zeke Kelso with a transmitter, giving instructions to his colleague) and attempts to find out what is happening. Her echo questions (addressed to her sister Patti and Zeke Kelso) may be viewed as a refusal to keep silent, which in the first case is caused by a misunderstanding and in the second also expresses indignation at Zeke Kelso's seemingly impudent behaviour: entering Ingrid's bedroom without her permission, staying there, and refusing to answer any questions as to the aim of his visit.

Conclusions. In conversational discourse, echo questions may be realized as direct speech acts (quesitives) as well as combine several illocutions functioning as indirect directives, expressives, metacommunicatives, constatives, and commissives. Quesitives embrace requesting elaboration / clarification / repetition, checking an inference / assumption, and asking for confirmation / commitment. A directive may take the form of an injunctive (order), requestive (recommendation / advice / request), or disagreement-directive. A metacommunicative maintains speech contact by expressing empathy and interest, while a constative combines informing and inquiring. A commissive may function as a promisive / asking for instructions, menasive, and refusal.

\section{REFERENCES}

1. Гладуш Н. Ф. Прагматичні аспекти висловлення і дискурсу. К. : Вид. центр КНЛУ, 2005. 200 с.

2. Зербіно А. Д. Лінгвопрагматика висловлень згоди / незгоди та засоби їх вираження в сучасному художньому англомовному дискурсі : автореф. дис. на здобуття наук ступеня канд. філол. наук : спец. 10.02.04 "Германські мови". Львів, 2013. 19 с.

3. Конрад Р. Вопросительные предложения как косвенные речевые акты // Новое в зарубежной лингвистике. 1985. Вып. 16 : Лингвистическая прагматика. С. 349-383.

4. Мороховский А. Н., Воробьева О. П., Лихошерст Н. И., Тимошенко 3. В. Стилистика английского языка. К. : Выща шк., 1991. 272 с.

5. Осовська I. М. Висловлювання-відмова: структурносемантичний та комунікативно-прагматичний аспекти (на матеріалі сучасної німецької мови) : автореф. дис. на здобуття наук. ступеня канд. філол. наук : спец. 10.02 .04 "Германські мови". К., 2003. 20 с.

6. Почепцов Г. Г. Избранные труды по лингвистике : монография / сост., общ. ред. и вступ. статья И. С. Шевченко. Харьков : ХНУ имени В. Н. Каразина, 2009. 556 с.

7. Стрельченко Н. С. Питання-перепити в системі мовленнєвих актів // Україна і світ: діалог мов та культур : матеріали міжнар. наук.-практ. конф., Київ, 30 берез. -1 квіт. 2016 р. К. : Вид. центр КНЛУ, 2016. С. 399-401.

8. Стрельченко Н. С. Питання-перепити у термінологічному

аспекті // Наукові записки Кіровоградського державного педагогічного університету. Серія: Філологічні науки (мовознавство). 2015. Вип. 138. С. 243-248.

9. Шевченко И. С. Историческая динамика прагматики предложения: английское вопросительное предложение 16-20 вв. : монография. Харьков : Константа, 1998. 168 с.

10. A Murder is announced : [motion picture] / directed by D. Giles. BBC, 1985. 153 min.

11. Austin J. L. How to do things with words. Oxford : Oxford University Press, 1962. 167 p.

12. Bach K., Harnish R. M. Meaning, speech acts and communication. Cambridge, Massachusetts : The MIT Press, 1979. $327 \mathrm{p}$.

13. Caponigro I., Sprouse J. Rhetorical questions as questions // Proceedings of Sinn und Bedeutung / edited by E. PuigWaldmüller. Barcelona : Universitat Pompeu Fabra, 2007. P. 121-133.

14. Carter R., McCarthy M. Cambridge grammar of English. Cambridge : Cambridge University Press, 2006. 973 p.

15. Cat among the pigeons : [motion picture] / directed by J. Kent. ITV Productions, 2008. $93 \mathrm{~min}$.

16. Christie A. Selected detective prose. Moscow : Raduga Publishers, 1989. $398 \mathrm{p}$.

17. Deadly slumber: [motion picture] / directed by S. Orme. Zenith Entertainment, 1993. 103 min.

18. Doyle A. C. The Case-book of Sherlock Holmes. Ware : 
Wordsworth Editions Limited, 1993. 1126 p. ings of the 16th Amsterdam Colloquium / edited by P. Dekker. Universiteit van Amsterdam, 2007. P. 73-78.

20. Four and Twenty Blackbirds: [motion picture] / directed by R. Rye. Picture Partnership Productions, 1989. $50 \mathrm{~min}$.

21. Fraser B. Towards a theory of discourse markers // Approaches to discourse particles / edited by K. Fischer. Amsterdam : Elsevier, 2006. P. 189-204.

22. Hickory Dickory Dock: [motion picture] / directed by A. Grieve. Carnival Film \& Television, 1995. $103 \mathrm{~min}$.

23. Leech G. N. Principles of pragmatics. London : Longman, 1983. $250 \mathrm{p}$.

24. Lewis D. M. Discourse markers in English: a discoursepragmatic view // Approaches to discourse particles / edited

25. Norrick N. R. Discourse markers in oral narrative // Journal of Pragmatics. 2001. Vol. 33. P. 849-878.

26. Rohde H. Rhetorical questions as redundant interrogatives // San Diego Linguistics Papers. 2006. Issue 2. P. 134-168.

27. Schaffer D. Can rhetorical questions function as retorts? Is the Pope Catholic? // Journal of Pragmatics. 2005. Vol. 37. P. 433-460.

28. Schiffrin D. Discourse marker research and theory: revisiting and // Approaches to discourse particles / edited by K. Fischer. Amsterdam : Elsevier, 2006. P. 315-338.

29. Searle J. What is a speech act? // Philosophy in America / edited by M. Black. London : Allen and Unwin, 1965. P. 221239.

30. Strelchenko N. Echo questions functioning as quesitive
19. Egg M. Meaning and use of rhetorical questions // Proceedby K. Fischer. Amsterdam : Elsevier, 2006. P. 43-59.

speech acts in conversation // The 6th international research conference on education, language and literatures : Conference proceedings, Tbilisi, 22-23 April 2016. Tbilisi : International Black Sea University, 2016. P. 181-184.

31. That darn cat: [motion picture] / directed by R. Stevenson. Walt Disney Productions, 1965. $116 \mathrm{~min}$.

32. The double clue: [motion picture] / directed by A. Piddington. ITV Productions, 1991. $50 \mathrm{~min}$.

33. The Grim Reaper : [motion picture] / directed by M. Carter. $\mathrm{BBC}, 2014.44 \mathrm{~min}$

34. The Hollow: [motion picture] / directed by S. Langton. Granada Television, 2004. 93 min.

35. The Infernal Serpent : [motion picture] / directed by J. Madden. Zenith Productions, 1990. $105 \mathrm{~min}$.

36. The Maddest of All : [motion picture] / directed by M. Carter. BBC, 2014. 44 min.

37. The Plymouth Express : [motion picture] / directed by A. Piddington. Picture Partnership Productions, 1991. 50 min.

38. Why didn't they ask Evans? : [motion picture] / directed by J. Davies, T. Wharmby. London Weekend Television, 1980. $180 \mathrm{~min}$.

39. Wunderlich D. Methodological remarks on speech act theory // Speech act theory and pragmatics / edited by J. R. Searle, F. Kiefer, M. Bierwisch. Dordrecht : Reidel Publishing Company, 1980. P. 291-312.

40. Yang Li-chiung Integrating prosodic and contextual cues in the interpretation of discourse markers // Approaches to discourse particles / edited by K. Fischer. Amsterdam : Elsevier, 2006. P. 265-297

REFERENCES (translated and transliterated)

1. Gladush N. F. Pragmatic aspects of the utterance and discourse. Kyiv : Vyd. tsentr KNLU, 2005. 200 p.

2. Konrad R. Interrogative sentences as indirect speech acts // New research in foreign linguistics. 1985. Vol. 16 : Linguistic pragmatics. P. 349-383.

3. Morokhovskij A. N., Vorobyova, O. P., Likhosherst N. I., Timoshenko Z. V. English stylistics. Kyiv : Vyshcha shkola, 1991. $272 \mathrm{p}$.

4. Osovska I. M. Utterances of refusal: structural, semantic, communicative and pragmatic aspects (on the material of modern German language) : candidate dissertation synopsis : speciality 10.02.04 "Germanic languages". Kyiv, 2003. 20 p.

5. Pocheptsov G. G. Selected works in linguistics. Kharkiv : HNU imeni V. N. Karazina, 2009. 556 p.
6. Shevchenko I. S. Historical dynamics of the pragmatics of the sentence: The English interrogative sentence of 16th-20th centuries. Kharkiv : Konstanta, 1998. 168 p.

7. Strelchenko N. S. Echo questions from the terminological point of view // Scientific papers of Kirovograd State Pedagogical University. Series: Philology (Linguistics). 2015. Issue 138. P. 243-248.

8. Strelchenko N. S. Echo questions in the system of speech acts // Ukraine and the world: a dialogue of languages and cultures : conference proceedings, Kyiv, 30 March - 1 April 2016. Kyiv : Vyd. tsentr KNLU, 2016. P. 399-401.

9. Zerbino A. D. The lingual-pragmatic study of utterances expressing agreement / disagreement and means of their realization in modern English artistic discourse : candidate dissertation synopsis : speciality 10.02.04 "Germanic languages". Lviv, 2013. 19 p. 